\title{
Genotype-corrected reference values for serum angiotensin-converting enzyme
}

\author{
H. Biller*, G. Zissel*, B. Ruprecht ${ }^{\#, \mp, ~ M . ~ N a u c k ~}{ }^{+, \S}$, A. Busse Grawitz \\ and J. Müller-Quernheim*
}

ABSTRACT: The deletion (D)/insertion (I) polymorphism in intron 16 of the angiotensinconverting enzyme (ACE) gene has the greatest impact on serum ACE level in Caucasians of any factor yet discovered. The aim of the present study was to establish new ACE genotype-corrected normal ranges for serum ACE level in a population of central European origin.

After a medical examination, 159 healthy Caucasians volunteered to donate blood for the study. ACE genotypes were assessed by PCR and serum ACE levels were determined using two different kinetic tests.

The distribution of the D/I polymorphism of the ACE gene was in accordance with the HardyWeinberg equilibrium. Serum ACE levels and ACE genotypes correlated significantly, with the highest serum ACE levels in subjects with ACE genotype $D / D$, and the lowest serum ACE levels in subjects with genotype $\mathrm{I} / \mathrm{I}$ (mean $\pm \mathrm{SD}$, assay 1 : $\mathrm{D} / \mathrm{D} 59.3 \pm 15.1 \mathrm{U} \cdot \mathrm{L}^{-1}, \mathrm{D} / \mathrm{I} 45.5 \pm 15.2 \mathrm{U} \cdot \mathrm{L}^{-1}, \mathrm{I} / \mathrm{I}$ $34.8 \pm 13.7 \mathrm{U} \cdot \mathrm{L}^{-1}$; assay 2: D/D $43.7 \pm 14.1 \mathrm{U} \cdot \mathrm{L}^{-1}, \mathrm{D} / \mathrm{I} 33.7 \pm 12.1 \mathrm{U} \cdot \mathrm{L}^{-1}, \mathrm{I} / \mathrm{I} 25.4 \pm 9.5 \mathrm{U} \cdot \mathrm{L}^{-1}$ ). Although they gave different absolute values of serum ACE levels, the results of the two test kits correlated significantly.

In conclusion, the present authors recommend the use of new, genotype-specific reference values for serum angiotensin-converting enzyme levels, especially to improve the sensitivity and specificity of tests for angiotensin-converting enzyme in the follow-up of sarcoidosis.

KEYWORDS: Angiotensin-converting enzyme, deletion/insertion polymorphism, PCR, reference value, sarcoidosis

A ngiotensin I-converting enzyme (ACE; dipeptidyl carboxypeptidase I; Enzyme Commission (EC) 3.4.15.1) is a peptidyldipeptide hydrolase belonging to the class of zinc metalloproteases. It has a major role in the metabolism of vasoactive peptides, converting the decapeptide angiotensin I into the active octapeptide angiotensin II, and hydrolysing the vasodilator peptide bradykinin. ACE has been found in many different cell types, including neuronal cells, renal proximal tubular cells, endothelial cells and cells of the monocytemacrophage system. It is attached to the endothelial surface membrane by an anchor peptide, and can be cleaved, resulting in its release into the blood circulation as a soluble enzyme [1-3].

Serum ACE level is often elevated in patients with untreated active sarcoidosis [4], and spontaneous or corticosteroid-induced remission of sarcoidosis can be heralded by decreasing serum ACE values [5]. Measurement of serum ACE is thus a tool in the monitoring of sarcoidosis. However, although serum ACE concentrations are remarkably stable when measured repeatedly in a single healthy person, there are large interindividual differences [6]. Thus, the wide reference range of plasma ACE levels hampers the interpretation of ACE values in a clinical setting. CAMBIEN et al. [7] found similar serum ACE concentrations in consanguineous family members, suggesting that ACE levels are subject to a strong genetic influence. This was confirmed when a deletion (D)/insertion (I) polymorphism in the ACE gene was found [8], which was later defined precisely by the presence or absence of a 287-bp DNA fragment in intron 16 of the ACE gene. This polymorphism is reported to be associated with $\leqslant 28 \%$ of the variation in serum ACE level [9], depending on the ethnic background of the population examined. In a study employing a large Nigerian cohort, Cox et al. [10] reported that $33 \%$ of the variance in ACE serum level was explained by genetic variation, while $19 \%$ was explained by residual familial correlations [10]. The remaining $48 \%$, however, was dependent on random individual-specific factors.

Studies of the D/I polymorphism in the ACE gene have shown the $\mathrm{D}$ allele to be associated
AFFILIATIONS

*Depts of Pneumology, and, ${ }^{+}$Clinical Chemistry, Medical Centre, University Hospital Freiburg, Freiburg, and,

\# Medical Hospital, Research Centre Borstel, Borstel, and,

-Medical Dept I, Herford General Hospital, Herford, and

${ }^{\S}$ Bioscientia Institute for Laboratory Diagnostics, Ingelheim, Germany.

CORRESPONDENCE

J. Müller-Quernheim Dept of Pneumology Medical Center University of Freiburg Killianstr. 5

D-79104 Freiburg Germany Fax: 497612703704 E-mail: jmq@medizin.ukl.unifreiburg.de

Received:

April 112006

Accepted after revision:

October 022006
European Respiratory Journal Print ISSN 0903-1936 Online ISSN 1399-3003 
with enhanced ACE activity, and the I allele with lower ACE activitiy [8, 11]. Although the idea of exploiting the D/I polymorphism to improve the clinical value of ACE serum levels is not new, the lack of any definition of reference values according to patient ACE genotype has been noted [8, 12, 13].

The aim of the present study, therefore, was to establish new reference ranges for serum ACE levels in healthy subjects from Germany, in accordance with their ACE D/I genotype.

\section{MATERIALS AND METHODS}

\section{Subjects}

In the present study, 159 healthy adult Caucasians from northern Germany were employed (53 male: mean \pm SD age $36.5 \pm 10.7$ yrs, range 18-61 yrs; 106 female: age $37.7 \pm 11.7$ yrs, 19-64 yrs). Participants were hospital employees who volunteered to donate blood after an examination by the occupational medical service of the Research Centre Borstel (Borstel, Germany). All of the subjects were judged healthy. None of them was on any medication. In particular, subjects were asked about ACE inhibitors. All subjects included in the study denied being on such medication. Informed consent was obtained from all participants.

\section{DNA extraction and PCR}

DNA was extracted from anticoagulated venous blood samples using TRIZOL (Invitrogen, Carlsbad, CA, USA). The $\mathrm{D}$ and I alleles were identified on the basis of PCR amplification of the relevant fragments from intron 16 of the ACE gene, followed by size fractionation and visualisation by gel electrophoresis.

The relevant fragment in intron 16 of the ACE gene was amplified according to the method of RIGAT et al. [14], as previously described [15]. Briefly, DNA was amplified in a 25$\mu \mathrm{L}$ mixture containing $2.5 \mathrm{mM} \mathrm{MgCl}_{2}, 5$ pmol of each primer (primer 1: TGG AGA GCC ACT CCC ATC CTT TCT; primer 2: GAC GTG GCC ATC ACA TTC GTC AGA T; MWG-Biotech AG, Ebersberg, Germany), $0.2 \mathrm{mM}$ of each deoxyribonucleoside triphosphate (Invitrogen), $0.5 \mathrm{U}$ of Taq polymerase (Invitrogen) and $2.5 \mu \mathrm{L} 10 \times$ PCR Buffer (Invitrogen). The PCR ran as follows: 5-min initial denaturation at $95^{\circ} \mathrm{C}$; followed by 30 cycles of $30 \mathrm{~s}$ at $94^{\circ} \mathrm{C}$ (denaturation), $30 \mathrm{~s}$ at $54^{\circ} \mathrm{C}$ (annealing) and $1 \mathrm{~min}$ at $72^{\circ} \mathrm{C}$ (extension); followed by a final elongation step at $72^{\circ} \mathrm{C}$ for $5 \mathrm{~min}$. The presence of the $\mathrm{D}$ allele resulted in a $192 \mathrm{bp}$ PCR product, while the I allele resulted in a $479 \mathrm{bp}$ PCR product. Owing to the preferential amplification of the D allele in heterozygous samples, all samples found to have the D/D genotype were included in a second insertion-specific PCR (primer 1: TGG GAC CAC AGC GCC CGC CAC TAC; primer 2: TCG CCA GCC CTC CCA TGC CCA TAA; MWG-Biotech AG). The reaction buffer differed from the previous reaction in that it contained $5 \%$ DMSO (Sigma-Aldrich, Munich, Germany) and $1.5 \mathrm{mM}$ $\mathrm{MgCl}_{2}$. The PCR conditions were as follows: $5 \mathrm{~min}$ initial denaturation at $95^{\circ} \mathrm{C}$; followed by 30 cycles of $30 \mathrm{~s}$ at $94^{\circ} \mathrm{C}, 45 \mathrm{~s}$ at $62^{\circ} \mathrm{C}$ and $40 \mathrm{~s}$ at $72^{\circ} \mathrm{C}$; followed by a final elongation step at $72^{\circ} \mathrm{C}$ for $5 \mathrm{~min}$. The presence of an I allele resulted in a $335 \mathrm{bp}$ PCR product, whereas for samples homozygous for $\mathrm{D} / \mathrm{D}$, no products could be detected [16, 17].
Real-time PCR was performed in $20 \mu \mathrm{L}$ iQ SYBR Green Supermix (Bio-Rad, Hercules, CA, USA) containing 5 pmol of each primer, as described above, and 5 ng DNA. PCR was run in a three-step protocol at $95^{\circ} \mathrm{C}, 57^{\circ} \mathrm{C}$ and $72^{\circ} \mathrm{C}$ on an iQ RealTime Detection System (Bio-Rad). After 45 cycles, a melting curve employing a temperature increase of $0.2^{\circ} \mathrm{C} \cdot 10 \mathrm{~s}^{-1}$ was started.

\section{Serum ACE measurement}

Serum ACE was determined photometrically by two different commercially available kinetic tests, purchased from Bühlmann Laboratories AG (Allschwil, Switzerland; assay 1) and from Trinity Biotech (Bray, Ireland; assay 2). Testing was performed according to the manufacturers' instructions. ACE catalyses the hydrolysation of the synthetic substance N-[3-(2furyl)acryloyl]-L-phenylalanylglycylglycine (assay 1) [4, 18] or hippuryl-L-histidyl-L-leucine (assay 2) [19]. This hydrolysis results in a decrease in absorbance at $340 \mathrm{~nm}$, which is measured in both tests.

\section{Statistical methods}

Data are presented as mean \pm SD. The correlation between ACE genotype and serum ACE level was analysed using the ANOVA test. Correlations were estimated using correlation matrices with Fisher's $\mathrm{r}$ to $\mathrm{z}$ as post hoc test and Bartlett's test of sphericity. For comparisons of two groups, p-values $<0.05$ were regarded as statistically significant. For multiple comparisons, p-values were corrected for the number of groups (0.5/ $(n-1))$. Differences between the genotype frequencies within the current study group and the expected frequencies as calculated by the law of Hardy and Weinberg were estimated using Chi-squared tests.

\section{RESULTS}

\section{Distribution of ACE genotypes}

In all cases, initial PCR was successful. Due to the length difference, the I allele band in D/I genotypes is weaker than the $\mathrm{D}$ allele band (fig. 1a). Therefore, apparent D/D cases were further investigated employing an insertion-specific primer. This protocol warrants that in every case the correct genotype is determined. The absence of a product in this second PCR reaction confirmed the $\mathrm{D} / \mathrm{D}$ phenotype. The results of the conventional PCR were in line with results obtained by realtime PCR (fig. 1b).

The homozygous genotype D/D was present in $29.6 \%$ of the subjects in the present study, $24.5 \%$ were homozygous for the I/I genotype, and $45.9 \%$ of subjects had the heterozygous genotype $\mathrm{D} / \mathrm{I}$. The distribution of genotypes was in accordance with the Hardy-Weinberg equilibrium (genotype frequency $0.30 ; 0.46 ; 0.24$ for $\mathrm{D} / \mathrm{D}, \mathrm{D} / \mathrm{I}$ and $\mathrm{I} / \mathrm{I}$, respectively).

There were no significant differences between genotype frequencies between males and females.

\section{Serum ACE levels with regard to ACE genotype}

The overall mean serum ACE level detected by assay 2 was $34.6 \pm 13.8 \mathrm{U} \cdot \mathrm{L}^{-1}$ (fig. 2). Based on these results, an upper limit to the normal range of serum ACE levels of $62 \mathrm{U} \cdot \mathrm{L}^{-1}$ was calculated. This coincides exactly with the value provided by the manufacturer. The overall mean serum ACE level detected by assay 1 was $47.0 \pm 17.3 \mathrm{U} \cdot \mathrm{L}^{-1}$, leading to an upper limit to 

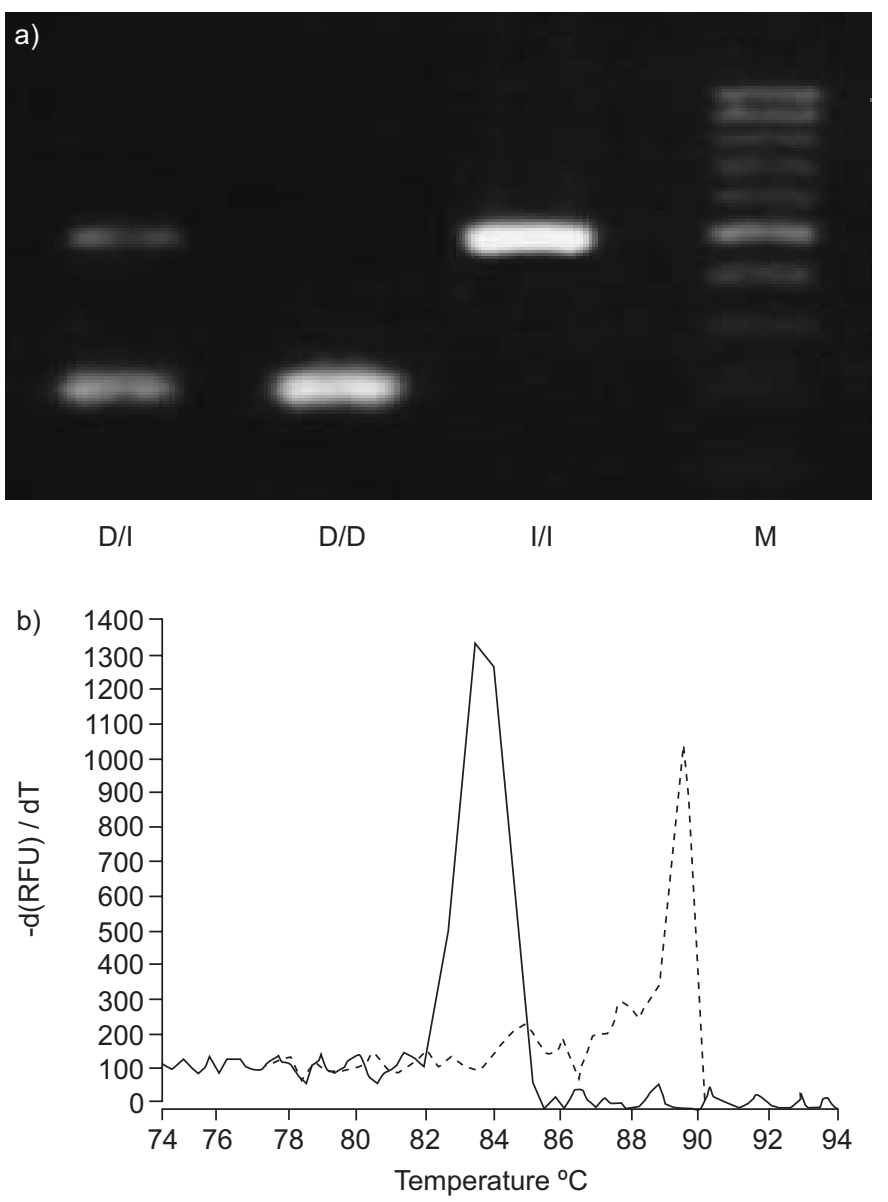

FIGURE 1. Examples of angiotensin-converting enzyme genotyping. a) Visualisation of the PCR products on a $2 \%$ agarose gel. The presence of a 192bp PCR product indicates a deletion (D)/D genotype; the presence of a 479-bp PCR product designates the insertion (I)/I genotype. Heterozygotes $(\mathrm{D} / \mathrm{l})$ are shown by the presence of both bands. b) Genotyping by melting curve. The length polymorphism, together with an increased GC content, results in an increase in the melting temperature of the I allele. A single peak at $83.5^{\circ} \mathrm{C}(-)$ indicates a D/ D genotype; a single peak at $89.5^{\circ} \mathrm{C}(-----)$ indicates an $\mathrm{I} / \mathrm{l}$ genotype. The $\mathrm{D} / \mathrm{I}$ genotype is indicated by the presence of both peaks (data not shown). M: size markers; $d(R F U) / d T$ : change in relative fluorescence over temperature.

the normal range value of $81 \mathrm{U} \cdot \mathrm{L}^{-1}$, which is close to the value provided by the company $\left(79 \mathrm{U} \cdot \mathrm{L}^{-1}\right)$. This high reproducibility of the upper limits indicate that the individuals selected in the present cohort are suitable for the study, because they resemble the cohorts originally used to establish the thresholds.

Using assay 2: the mean serum ACE in subjects with genotype $\mathrm{D} / \mathrm{D}$ was $43.7 \pm 14.1 \mathrm{U} \cdot \mathrm{L}^{-1}$; in those with genotype $\mathrm{D} / \mathrm{I}$, mean serum ACE was $33.7 \pm 12.1 \mathrm{U} \cdot \mathrm{L}^{-1}$; and in those with genotype $\mathrm{I} / \mathrm{I}$, mean serum $\mathrm{ACE}$ was $25.4 \pm 9.5 \mathrm{U} \cdot \mathrm{L}^{-1}$. Using assay 1: the mean serum ACE in subjects with genotype $D / D$ was $59.3 \pm 15.1 \mathrm{U} \cdot \mathrm{L}^{-1}$; in those with genotype $\mathrm{D} / \mathrm{I}$, mean serum ACE was $45.5 \pm 15.2 \mathrm{U} \cdot \mathrm{L}^{-1}$; and in those with genotype I/I, mean serum ACE was $34.8 \pm 13.7 \mathrm{U} \cdot \mathrm{L}^{-1}$. Regardless of the test kit used, there was a highly significant correlation between ACE genotype and serum level, as determined by ANOVA $(p<0.0001)$. Distribution analysis of the ACE concentrations

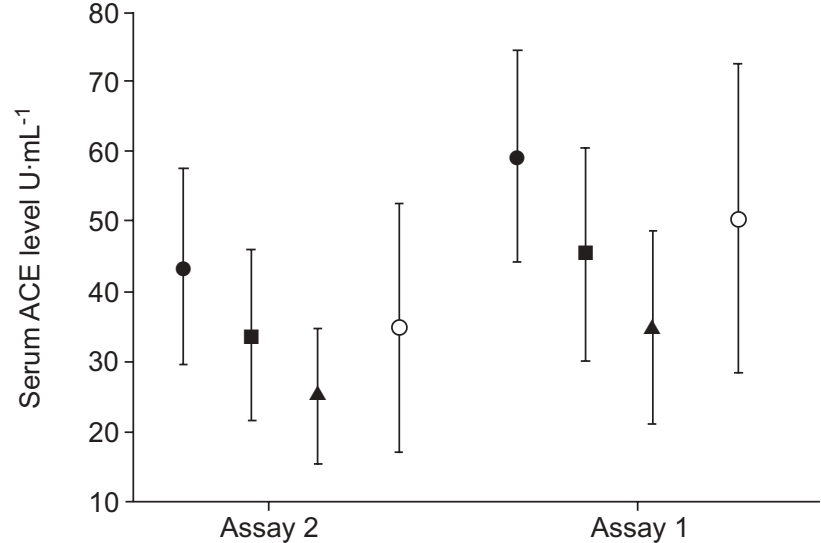

FIGURE 2. Mean serum angiotensin-converting enzyme (ACE) levels of patients with different ACE genotypes. Serum ACE levels were determined colorimetrically using two different assays as described in the Materials and Methods section. Serum ACE levels and the ACE genotypes showed a significant correlation $(p<0.0001)$. Data are presented as mean \pm SD. $\bullet$ : deletion $(D) / D$; $\boldsymbol{\square}$ : D/insertion (I); $\boldsymbol{\Delta}: \mathrm{I} / \mathrm{I} ; \mathrm{O}$ : the ACE level of the entire cohort without regard to genotype.

revealed a Gaussian distribution of the values in all three genotypes. Owing to the normal distribution of the ACE concentrations and the Hardy-Weinberg equilibrium of the genotypes, no additional statistical analysis, as applied for genotypes not following the Hardy-Weinberg equilibrium or whose frequencies are not normally distributed, were performed.

Table 1 shows the $95 \%$ confidence intervals (mean $\pm 1.96 \mathrm{sD}$ ) for the serum ACE levels for each genotype, suggesting new clinical reference intervals for serum ACE levels. When using assay 2, an upper reference level of $71 \mathrm{U} \cdot \mathrm{L}^{-1}$ is suggested for individuals with genotype $\mathrm{D} / \mathrm{D}$, an upper limit of $57 \mathrm{U} \cdot \mathrm{L}^{-1}$ for those with genotype $\mathrm{D} / \mathrm{I}$ and an upper reference value of $44 \mathrm{U} \cdot \mathrm{L}^{-1}$ for those with genotype I/I. For assay 1, upper reference levels of $89 \mathrm{U} \cdot \mathrm{L}^{-1}, 75 \mathrm{U} \cdot \mathrm{L}^{-1}$ and $62 \mathrm{U} \cdot \mathrm{L}^{-1}$ are suggested for individuals with genotype $\mathrm{D} / \mathrm{D}, \mathrm{D} / \mathrm{I}$, and I/I, respectively. These values differ significantly from those delineated from the entire cohort, not corrected for genotypes (assay 1: $79 \mathrm{U} \cdot \mathrm{L}^{-1}$; assay 2: $62 \mathrm{U} \cdot \mathrm{L}^{-1}$ ).

\section{Influence of age and sex on serum ACE levels}

There was no correlation between serum ACE levels and age within the present study group, regardless of the test employed.

Interestingly, the results of assay 1 suggested that males had significantly higher serum ACE levels than females $\left(51.4 \mathrm{U} \cdot \mathrm{L}^{-1}\right.$ versus $45 \mathrm{U} \cdot \mathrm{L}^{-1}$, respectively; $\mathrm{p}<0.05$ ). This difference was not shown by assay $2\left(36.6 \mathrm{U} \cdot \mathrm{L}^{-1}\right.$ versus $33.8 \mathrm{U} \cdot \mathrm{L}^{-1}$, respectively; not significant). When the results were broken down by genotype, a male-female difference was apparent only in individuals with the $\mathrm{D} / \mathrm{I}$ genotype. Interestingly, this difference was shown up by both assay 1 (male: $52.5 \mathrm{U} \cdot \mathrm{L}^{-1}$; female: $41.6 \mathrm{U} \cdot \mathrm{L}^{-1} ; \mathrm{p}<0.005$ ) and assay 2 (male: $38.6 \mathrm{U} \cdot \mathrm{L}^{-1}$; female: $\left.30.8 \mathrm{U} \cdot \mathrm{L}^{-1} ; \mathrm{p}<0.005\right)$. 


\begin{tabular}{|c|c|c|c|c|}
\hline \multirow[t]{3}{*}{ TABLE 1} & \multicolumn{4}{|c|}{$\begin{array}{l}\text { Genotype-corrected reference values for serum } \\
\text { angiotensin-converting enzyme (ACE) }\end{array}$} \\
\hline & \multirow{2}{*}{\multicolumn{2}{|c|}{ Subjects $\mathrm{n}$}} & \multicolumn{2}{|c|}{ ACE levels $U \cdot L^{-1}$} \\
\hline & & & Assay 1 & Assay 2 \\
\hline \multicolumn{3}{|c|}{$\begin{array}{l}\text { Manufacturers' } \\
\text { reference values }\end{array}$} & 79 & 62 \\
\hline \multicolumn{5}{|l|}{ Genotype } \\
\hline All individua & & 159 & $12-82$ & $7-62$ \\
\hline $\mathrm{D} / \mathrm{D}$ & & 47 & 30-89 & $16-71$ \\
\hline $\mathrm{D} / \mathrm{I}$ & & 73 & $16-75$ & $10-57$ \\
\hline $1 / 1$ & & 39 & $8-62$ & $7-44$ \\
\hline
\end{tabular}

Data are presented as $95 \%$ confidence intervals (arithmetic mean $\pm 1.96 \mathrm{SD}$ ), unless otherwise stated. D: deletion; I: insertion.

\section{Correlation of ACE serum levels as detected by the two kits employed}

Serum ACE levels in 159 samples were measured using both ACE test kits. There was a significant correlation between the ACE serum levels detected by the two methods $(p<0.0001$, $\mathrm{r}=0.8$; fig. 3).

\section{Clinical relevance}

Figure 4 shows examples of the serum ACE course of sarcoidosis patients of each genotype. Most informative is patient A (genotype I/I; fig. 1a). After successful therapy, the patient's ACE level at day 1 was normal. At day 129, however, the patient suffered from deterioration requiring corticosteroid therapy. Nevertheless, serum ACE remained in the uncorrected normal range. However, use of the corrected range for the I/I genotype disclosed that the patient's serum ACE level was in fact elevated during the deterioration. After reaching a remission, a normal value was again observed. Thus, a change in granuloma burden did not disclose its pathogenetic relevance when the uncorrected reference values were used.

For patient B (genotype D/I; fig. 4b), genotype-corrected values are not relevant. At day 280, the patient presented with increased serum ACE activity, whereas at all other days serum ACE level was within the normal range, regardless of whether the values were genotype-corrected. However, genotype correction lead to a lower threshold and the exclusion of any homozygotes results in higher specificity and sensitivity of the test. On the basis of uncorrected values, patient $C$ (genotype D/D; fig. 4c) appears to have increased serum ACE activity at every time-point, despite being in remission at day 1 . Based on genotype-corrected values, serum ACE at day 1 is within the normal range, whereas at the other time-points this patient has elevated levels, which is in accordance with progressing disease. The disease relapse was obvious 6 weeks later.

\section{DISCUSSION}

In the present study, a close correlation between the D/I polymorphism in the ACE gene and serum ACE levels in a healthy Caucasian population from Germany is described, as has been described previously in populations of other origins $[8,11]$. The highest serum levels of ACE were found in subjects

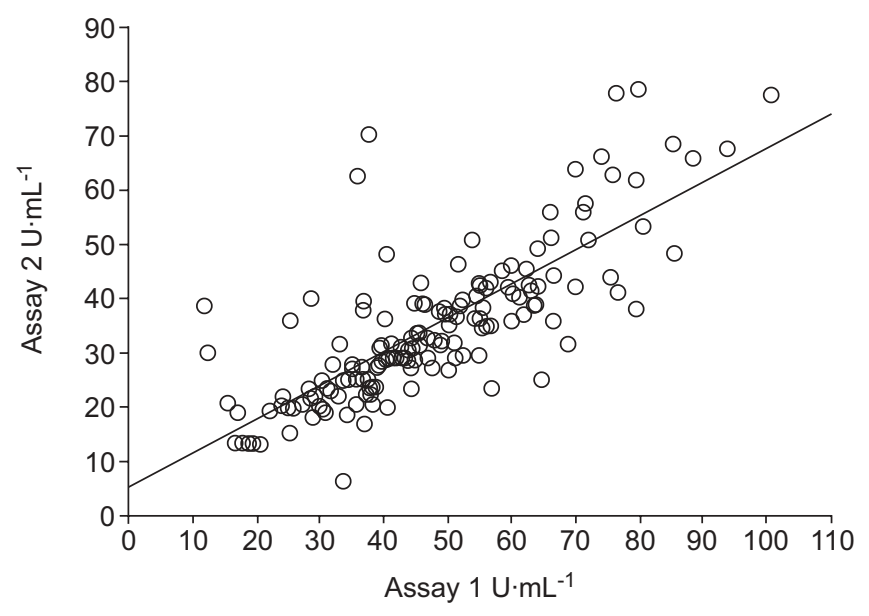

FIGURE 3. Correlation of serum angiotensin-converting enzyme (ACE) levels as detected by the two kits employed and measured according to the manufacturers' instructions. The correlation of serum ACE levels detected by the two different tests is shown $(r=0.8, p<0.0001)$.

with the homozygous genotype $\mathrm{D} / \mathrm{D}$, followed by those with the heterozygous genotype D/I. The lowest serum ACE levels were found in subjects with the homozygous genotype I/I. Based on these data, new reference intervals for serum ACE levels are suggested (table 1), taking into accound the patient's genotype.

The D/I polymorphism is located in a nontranscribed part (intron 16) of the ACE gene. In a study employing a large cohort from Nigeria, ZHU et al. [20] demonstrated that, rather than the D/I polymorphism itself, a single nucleotide polymorphism (SNP) in exon $17(\mathrm{~A} / \mathrm{G})$ and an additional SNP in the upstream untranslated region $\left(5^{\prime}-\mathrm{UTR} ; \mathrm{A} / \mathrm{T}\right)$ are responsible for the variation in ACE serum activity [20]. Again in a Nigerian cohort, Cox et al. [10] established a set of nine haplotypes defined by four different SNPs covering $80 \%$ of the observations in their cohort. Regarding serum ACE levels, five of these haplotypes disclose a very small confidence interval. Therefore, the possibility of using haplotypes, rather than the D/I polymorphism alone, was discussed in the literature. However, the situation in Caucasians is completely different. Within populations of African origin, a great variety of polymorphisms is found, and serum ACE levels are not linked to the D/I polymorphism [21]. In Caucasians, however, there are (grossly) eight different haplotypes, with only three haplotypes covering $90 \%$ of the observations [22]. In addition, these haplotypes exhibit a strong linkage disequilibrium. Therefore, analysing D/I polymorphisms instead of multiple SNP analysis is a simple and reliable approximation and is thought to mirror the functional SNP in exon 17. In addition, the simple method allows its usage in routine work. However, the new reference intervals suggested in this work cannot simply be adapted to other non-Caucasian populations.

As the current data indicate, using reference ranges as given by manufacturers without regarding genotypes might lead to misinterpretations of ACE serum levels. Normal ACE serum levels might be regarded, falsely, as elevated in subjects with ACE genotype D/D, whereas elevated ACE serum levels in 

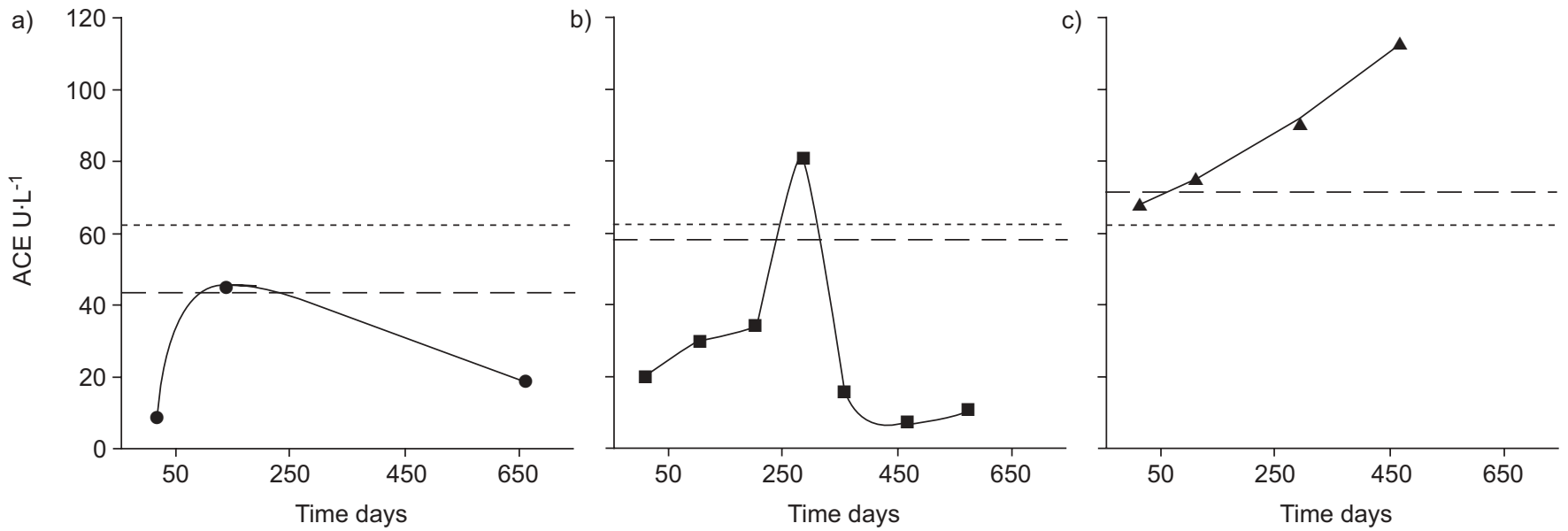

FIGURE 4. Clinical course of serum angiotensin-converting enzyme (ACE) activity from sarcoidosis patients. The graphs depict serum ACE levels, as measured by assay 2 in three patients from the current authors' outpatient clinic with genotypes: a) deletion (D)/D; b) D/insertion (I); and c) I/l. - - --: uncorrected limit for the test employed. - - -: corrected limits for $D / D\left(71 \mathrm{U} \cdot \mathrm{L}^{-1}\right), \mathrm{D} / \mathrm{I}\left(57 \mathrm{U} \cdot \mathrm{L}^{-1}\right)$ and $\mathrm{I} / \mathrm{I}\left(44 \mathrm{U} \cdot \mathrm{L}^{-1}\right)$ genotypes for assay 2

patients with ACE genotype I/I might falsely be interpreted as normal. The currently employed upper normal limits suggested by the manufacturers appear to be appropriate only for subjects with the heterozygous ACE genotype D/I (assay 1: $68 \mathrm{U} \cdot \mathrm{L}^{-1}$; assay 2: $52 \mathrm{U} \cdot \mathrm{L}^{-1}$ ). In addition, because average serum ACE levels in a heterogeneous population depend on the frequency of the three genotypes within this population, the uncorrected reference value should be adjusted according to the frequency distribution of the D/I genotypes. Using the genotype-related reference levels as suggested in the current study, a more precise interpretation of ACE serum levels will be possible. Moreover, because reference levels are established for a specific genetically defined subpopulation, the genetic composition of the population as a whole does not influence the reference values, which may thus be applied to all populations of Caucasian origin.

Although statistical analysis of the current data indicates that serum ACE levels are also dependent upon sex (at least using assay 1), this difference was not apparent in the D/D and I/I genotypes. Within the $\mathrm{D} / \mathrm{I}$ group, the difference between male and female is $11 \mathrm{U} \cdot \mathrm{L}^{-1}$ (assay 1) or $8 \mathrm{U} \cdot \mathrm{L}^{-1}$ (assay 2). It is possible that reference values for males and females, at least in the D/I genotype, might be helpful. Because females were overrepresented in the present study cohort, a bias towards lower reference values within the D/I genotype cannot be excluded. However, correcting the reference values for sex ratio revealed a difference of $<3 \mathrm{U} \cdot \mathrm{L}^{-1}$, which might be negligible in clinical routine.

As demonstrated by the clinical examples in figure 4 , the most important changes will be seen in the homozygote genotypes, because the differences between corrected and uncorrected upper limits are the greatest. In D/I genotypes, the upper levels are not greatly different. Interestingly, in patient A (fig. 4a), the genotype-corrected values indicated an increased ACE level compatible with the worsened clinical situation of this patient, whereas the uncorrected value did not reveal this course. From early indications, the present authors believe the genotype-corrected limits to be more informative.
The close relation between the ACE genotype and serum ACE levels has previously been described $[8,12,23]$. Owing to the use of different nonstandardised methods for ACE detection, the ACE serum levels described in those studies cannot be compared with each other, and reference ranges need to be established for every individual test [13]. In the current study, two of the most commonly employed laboratory tests for serum ACE level were used. Even though a significant correlation was found between the serum ACE levels detected by the tests, the absolute values differed. Therefore, the ACE reference intervals presented in the current study can only be applied if one of the two assays tested is used, on individuals of Caucasian origin. Laboratories using other systems and chemistries need to establish their own reference population and genotype-corrected reference values.

So far, interpretation of serum angiotensin-converting enzyme levels in the clinical monitoring of sarcoidosis patients has been difficult. In contrast to earlier reports showing an elevation of serum angiotensin-converting enzyme levels in sarcoidosis [4], it has long been known that patients with active and progressive sarcoidosis can also have normal or only slightly elevated serum angiotensin-converting enzyme levels [24-26]. In addition, the prognostic value of serum angiotensin-converting enzyme in sarcoid patients has been disputed. While some investigators suggest that the angiotensin-converting enzyme serum levels are reduced during therapy and increased in parallel to a relapse [5, 24], others could not find prognostic information in the serum angiotensin-converting enzyme levels of patients with sarcoidosis [25-29]. Thus, an individual approach to the interpretation of the serum angiotensin-converting enzyme level has been suggested, taking into account the trend of the individual patient's serum angiotensin-converting enzyme level rather than its absolute value [24]. Using genotype-corrected reference values, as introduced in the current study, will yield a higher sensitivity and specificity for the interpretation of serum angiotensin-converting enzyme levels. The current examples illustrate that the increase in sensitivity using genotype-corrected reference levels allows a differentiation of 
"increased" and normal serum angiotensin-converting enzyme levels that is parallelled by the clinical course of the patient. However, the exact gain in sensitivity and specificity still needs to be established in large follow-up studies of patients with sarcoidosis. Based on the current data, the present authors recommend the use of new, genotype-specific reference values for serum angiotensin-converting enzyme levels. Those laboratories which take care of patients of Caucasian origin and use one of the two kits tested can employ these genotype-corrected normal ranges.

\section{REFERENCES}

1 Erdös EG, Skidgel RA. The angiotensin I-converting enzyme. Lab Invest 1987; 56: 345-348.

2 Hubert C, Houot AM, Corvol P, Soubrier F. Structure of the angiotensin I-converting enzyme gene. Two alternate promoters correspond to evolutionary steps of a duplicated gene. J Biol Chem 1991; 266: 15377-15383.

3 Sibony M, Gasc JM, Soubrier F, Alhenc-Gelas F, Corvol P. Gene expression and tissue localization of the two isoforms of angiotensin I converting enzyme. Hypertension 1993; 21: 827-835.

4 Lieberman J. Elevation of serum angiotensin-convertingenzyme (ACE) level in sarcoidosis. Am J Med 1975; 59: 365372.

5 Lieberman J, Schleissner LA, Nosal A, Sastre A, Mishkin FS. Clinical correlations of serum angiotensin-converting enzyme (ACE) in sarcoidosis. A longitudinal study of serum ACE, ${ }^{67}$ gallium scans, chest roentgenograms, and pulmonary function. Chest 1983; 84: 522-528.

6 Alhenc-Gelas F, Weare JA, Johnson RL Jr, Erdos EG. Measurement of human converting enzyme level by direct radioimmunoassay. J Lab Clin Med 1983; 101: 83-96.

7 Cambien F, Alhenc-Gelas F, Herbeth B, et al. Familial resemblance of plasma angiotensin-converting enzyme level: the Nancy Study. Am J Hum Genet 1988; 43: 774-780.

8 Rigat B, Hubert C, Alhenc-Gelas F, Cambien F, Corvol P, Soubrier F. An insertion/deletion polymorphism in the angiotensin I-converting enzyme gene accounting for half the variance of serum enzyme levels. J Clin Invest 1990; 86: 1343-1346.

9 Tiret L, Rigat B, Visvikis S, et al. Evidence, from combined segregation and linkage analysis, that a variant of the angiotensin I-converting enzyme (ACE) gene controls plasma ACE levels. Am J Hum Genet 1992; 51: 197-205.

$10 \operatorname{Cox} \mathrm{R}$, Bouzekri N, Martin S, et al. Angiotensin-1converting enzyme (ACE) plasma concentration is influenced by multiple ACE-linked quantitative trait nucleotides. Hum Mol Genet 2002; 11: 2969-2977.

11 Delgado M, Gomariz RP, Martinez C, Abad C, Leceta J. Anti-inflammatory properties of the type 1 and type 2 vasoactive intestinal peptide receptors: role in lethal endotoxic shock. Eur J Immunol 2000; 30: 3236-3246.

12 Furuya K, Yamaguchi E, Itoh A, et al. Deletion polymorphism in the angiotensin I converting enzyme (ACE) gene as a genetic risk factor for sarcoidosis. Thorax 1996; 51: 777780 .

13 Sharma P, Smith I, Maguire G, Stewart S, Shneerson J, Brown MJ. Clinical value of ACE genotyping in diagnosis of sarcoidosis. Lancet 1997; 349: 1602-1603.
14 Rigat B, Hubert C, Corvol P, Soubrier F. PCR detection of the insertion/deletion polymorphism of the human angiotensin converting enzyme gene (DCP1) (dipeptidyl carboxypeptidase 1). Nucleic Acids Res 1992; 20: 1433.

15 Ruprecht B, Schurmann M, Ziegenhagen MW, et al. Korrigierte Normwerte fuer das Serum-ACE durch Genotzpisierung eines Deletions-/Insertions-polymorphismus des ACE-Gens. [Corrected normal values for serum ACE by genotyping the deletion-/insertion-polymorphism of the ACE gene]. Pneumologie 2001; 55: 326-332.

16 Shanmugam V, Sell KW, Saha BK. Mistyping ACE heterozygotes. PCR Methods Appl 1993; 3: 120-121.

17 Odawara M, Matsunuma A, Yamashita K. Mistyping frequency of the angiotensin-converting enzyme gene polymorphism and an improved method for its avoidance. Hum Genet 1997; 100: 163-166.

18 Hurst PL, Lovell-Smith CJ. Optimized assay for serum angiotensin-converting enzyme activity. Clin Chem 1981; 27: 2048-2052.

19 Hooper NM, Turner AJ. Isolation of two differentially glycosylated forms of peptidyl-dipeptidase A (angiotensin converting enzyme) from pig brain: a re-evaluation of their role in neuropeptide metabolism. Biochem J 1987; 241: 625633.

20 Zhu X, Bouzekri N, Southam L, et al. Linkage and association analysis of angiotensin I-converting enzyme (ACE)-gene polymorphisms with ACE concentration and blood pressure. Am J Hum Genet 2001; 68: 1139-1148.

21 Bloem LJ, Manatunga AK, Pratt JH. Racial difference in the relationship of an angiotensin I-converting enzyme gene polymorphism to serum angiotensin I-converting enzyme activity. Hypertension 1996; 27: 62-66.

22 Keavney B, McKenzie CA, Connell JM, et al. Measured haplotype analysis of the angiotensin-I converting enzyme gene. Hum Mol Genet 1998; 7: 1745-1751.

23 Niimi T, Tomita $H$, Sato $S$, et al. Vitamin D receptor gene polymorphism in patients with sarcoidosis. Am J Respir Crit Care Med 1999; 160: 1107-1109.

24 DeRemee RA, Rohrbach MS. Normal serum angiotensin converting enzyme activity in patients with newly diagnosed sarcoidosis. Chest 1984; 85: 45-48.

25 Ziegenhagen MW, Benner UK, Zissel G, Zabel P, Schlaak M, Müller-Quernheim J. Sarcoidosis: TNF- $\alpha$ release from alveolar macrophages and serum level of sIL-2R are prognostic markers. Am J Respir Crit Care Med 1997; 156: 1586-1592.

26 Ziegenhagen MW, Rothe ME, Schlaak M, MullerQuernheim J. Bronchoalveolar and serological parameters reflecting the severity of sarcoidosis. Eur Respir J 2003; 21: 407-413.

27 Prior C, Haslam PL. In vivo levels and in vitro production of interferon-gamma in fibrosing interstitial lung diseases. Clin Exp Immunol 1992; 88: 280-287.

28 Ainslie GM, Poulter LW, du Bois RM. Relation between immunocytological features of bronchoalveolar lavage fluid and clinical indices in sarcoidosis. Thorax 1989; 44: 501-509.

29 Rothkrantz-Kos S, van Dieijen-Visser MP, Mulder PG, Drent M. Potential usefulness of inflammatory markers to monitor respiratory functional impairment in sarcoidosis. Clin Chem 2003; 49: 1510-1517. 